\title{
Numerical analysis of prestressed hollow core slabs under long term loading
}

\section{Análise numérica de lajes alveolares protendidas submetidas a carregamentos de longa duração}
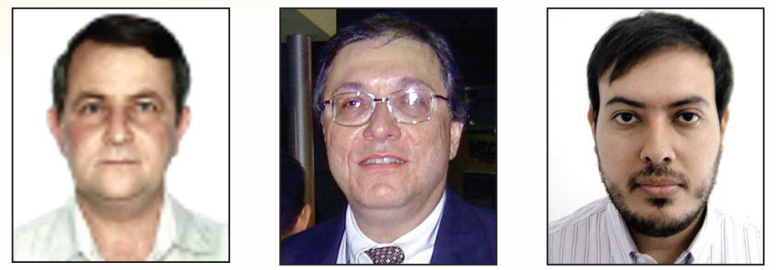

S. R. PEREIRA a ssrp@dees.ufmg.br

J. M. CALIXTO a calixto@dees.ufmg.br

T. P. BORTONE a thiagobortone@terra.com.br

\section{Abstract}

This paper presents a numerical analysis of prestressed hollow core slabs under long term loading. The model considers the time dependence of material and rheological properties in order to predict the actual stage of displacements, strains and stresses. It also takes into account load changes. For the analysis, each slab is divided in a finite number of bar elements, in which the cross section is described in concrete elements, parallel to the flexural axis, and prestressed steel elements. For the results evaluation, the effective concrete area is considered. The numerical results are compared with experimental tests performed on two series of prestressed hollow core slabs. Each series had a different geometry, rate and distribution of prestressing strands. Mid-span displacements were evaluated up to 127 days after initial loading. Good correlation was achieved with both series at and below the service load level.

Keywords: numerical analysis, prestressed concrete, hollow core slabs, long term loading.

\section{Resumo}

Este artigo apresenta os resultados de uma análise numérica de lajes alveolares protendidas extrudadas submetidas a carregamentos de longa duração. O modelo numérico considera os efeitos do tempo nas propriedades mecânicas dos materiais bem como nas propriedades reológicas, de modo a prever flechas, deformações e tensões. O modelo leva em conta também variações no carregamento. Para a análise, cada laje é subdividida em um número finito de elementos de barra cuja seção transversal é discretizada em elementos de concreto paralelos ao eixo de flexão, e elementos de armadura passiva. Para avaliação dos resultados é considerada a área líquida de concreto. Os resultados do modelo numérico foram comparados com valores medidos em ensaios de duas séries distintas de lajes alveolares protendidas. Cada série de lajes possuía diferentes geometrias, taxa e distribuição de cordoalhas. Deslocamentos no meio do vão de cada laje foram avaliados até a idade de 127 dias após o carregamento inicial. Boa correlação foi obtida com o modelo numérico para cargas menores ou iguais as de serviço.

Palavras-chave: análise numérica, lajes alveolares protendidas, carregamentos de longa duração. 


\section{Introduction}

A hollow core slab is a precast, prestressing concrete member with continuous voids provided to reduce weight and cost. They are primarily used as a floor deck system in residential and commercial buildings as well as in parking structures because they are economical, have good fire resistance and sound insulation properties, and are capable of spanning long distances with relatively small depths. Hollow core slabs can make use of prestressing strands, which allow slabs with depths between 150 and $260 \mathrm{~mm}$ to span over 9 meters.

When used in buildings, several hollow core slabs are placed next to each other to form a continuous floor system. The small gap that is left between each slab is usually filled with a non-shrink grout. To give the floor a smooth finished surface, a topping slab overlay is poured on the top surface of the hollow core slabs. This topping slab is typically $5 \mathrm{~cm}$ deep. The voids in a hollow core slab may be used for electrical or mechanical runs. For example, routing of a lighting circuit through the cores can allow fixtures in an exposed slab ceiling without unsightly surface mounted conduit.

Structurally, a hollow core slab provides the efficiency of a prestressed member for load capacity, span range, and deflection control. In addition, a basic diaphragm is provided for resisting lateral loads by the grouted slab assembly provided proper connections and details exist ( $\mathrm{PCl}$ [1]). The basic manufacturing method currently in use for the production of hollow core slabs is a dry cast or extrusion system where a very low slump concrete is forced through the machine. The cores are formed with augers or tubes with the concrete being compacted around the cores. In this scenario, the objective of this paper is to present a numerical analysis of prestressed hollow core slabs under long term loading. The modelling considers not only the load history of hollow core slabs but also the effects of time in the mechanical properties of the concrete. The slabs are divided in a number of elements each having different material properties as well as load histories. The results of the numerical analysis are compared to experimental tests performed on two series of prestressed hollow core slabs. Each series had a different geometry and rate and distribution of strands as well as material properties. Loads and mid-span displacements were evaluated up to 127 days after initial loading.

\section{The numerical model}

\subsection{Assumptions}

In the development of the numerical modelling [2], the following assumptions are introduced:

1. The hollow core slab, the applied loads and the deformations lie in a plane; the plane of loads is a plane of symmetry for the slab.

2. The slab is slender, that is, its length is much larger than its lateral dimensions.

3. Transverse and longitudinal displacements are infinitesimal.

4. Only normal strains parallel to the axis of the slab are considered.

5. The geometry of the slab can vary with respect to time as well along the length.

6. The material properties, in each section, can be different in each element

7. The effect of shrinkage, creep and cracking as well as the evolution of the mechanical properties of the concrete with time are taken into account.
8. The losses due to steel relaxation in the strands are also considered.

9. The applied loads vary along time.

\subsection{Formulation}

In the derivation of the model, the slab is divided in a number of sections, each of one composed of elements. These elements can have different geometrical and material properties as well load histories. It is assumed that at a generic time $\boldsymbol{t}_{u}$ the total strain in a concrete element $\boldsymbol{i}$ is known and given by:

$$
\varepsilon_{c i}\left(t_{u}, t_{0}\right)=\int_{t_{0}}^{t_{u}}\left(\frac{1}{E_{c}(\tau)}+\frac{\left.\varphi\left(t_{u}, \tau\right)\right)}{E_{c 28}}\right) \frac{d \sigma(\tau)}{d \tau} d \tau+\varepsilon_{c 5 s}\left[\beta_{s}\left(t_{u}\right)-\beta_{s}\left(t_{s}\right)\right]
$$

The total strain in this case includes the effects of the applied loads as well creep and shrinkage. These effects correspond to the first, second and third terms respectively of the right hand side in the equation above. The expression for the shrinkage strain and creep coefficient as well as the concrete tangent modulus of elasticity at time $\tau$ are the ones presented in NBR 6118 [3]. If a generic time interval $\left(\boldsymbol{t}_{u+1}-\boldsymbol{t}_{0}\right)$ is divided in a number of time steps, the total strain of each concrete element $\boldsymbol{i}$ in each section of the slab becomes:

$$
\begin{aligned}
& \varepsilon_{c i}\left(t_{u+1}, t_{0}\right)=\frac{1}{2} \sum_{j=1}^{u}\left(\frac{1}{E_{c}\left(t_{j}\right)}+\frac{1}{E_{c}\left(t_{j-1}\right)}+\frac{\varphi\left(t_{u+1}, t_{j}\right)+\varphi\left(t_{u+1}, t_{j-1}\right)}{E_{c 28}}\right) \Delta \sigma_{c i}\left(t_{j}, t_{j-1}\right) \\
& +\frac{1}{2} \sum_{j=1}^{u}\left(\frac{1}{E_{c}\left(t_{u+1}\right)}+\frac{1}{E_{c}\left(t_{u}\right)}+\frac{\varphi\left(t_{u+1}, t_{u+1}\right)+\varphi\left(t_{u+1}, t_{u}\right)}{E_{c 28}}\right) \Delta \sigma_{c i}\left(t_{u+1}, t_{u}\right) \\
& +\varepsilon_{c 50}\left[\beta_{s}\left(t_{u+1}\right)-\beta_{s}\left(t_{s}\right)\right]
\end{aligned}
$$

From equation (2) it can be seen that each concrete element can have different material and load history at every time step. It is important to point out that the creep effects are considered to the time step $\left(\boldsymbol{t}_{u+1}\right)$ and $\varphi\left(\boldsymbol{t}_{u+1}, \boldsymbol{t}_{u+1}\right)=\mathbf{0}$.

In equation (2) the incremental stress in each concrete element $\Delta \sigma_{c i}\left(t_{u+p}, t_{u}\right)$ can be explicitly determined if one rewrites the equation after splitting the second summation. Thus:

$$
\begin{aligned}
& \Delta \sigma_{c i}\left(t_{u+1}, t_{u}\right)=\frac{\varepsilon_{c i}\left(t_{u+1}, t_{0}\right)-\varepsilon_{c 50}\left[\beta_{s}\left(t_{u+1}\right)-\beta_{s}\left(t_{s}\right)\right]}{\frac{1}{2}\left(\frac{1}{E_{c}\left(t_{u+1}\right)}+\frac{1}{E_{c}\left(t_{u}\right)}+\frac{\varphi\left(t_{u+1}, t_{u}\right)}{\left.E_{c 28}\right)}\right)} \\
& -\frac{\frac{1}{2} \sum_{j=1}^{u}\left(\frac{1}{E_{c}\left(t_{j}\right)}+\frac{1}{E_{c}\left(t_{j-1}\right)}+\frac{\varphi\left(t_{u+1}, t_{j}\right)+\varphi\left(t_{u+1}, t_{j-1}\right)}{E_{c 28}}\right) \Delta \sigma_{c i}\left(t_{j}, t_{j-1}\right)}{\frac{1}{2}\left(\frac{1}{E_{c}\left(t_{u+1}\right)}+\frac{1}{E_{c}\left(t_{u}\right)}+\frac{\varphi\left(t_{u+1}, t_{u}\right)}{E_{c 28}}\right)}
\end{aligned}
$$


With this incremental stress, the final stress in each concrete element at time $t_{u+1}$ can be obtained as:

$$
\Delta \sigma_{c i}\left(t_{u+1}\right)=\sum_{j=1}^{u+1} \Delta \sigma_{c i}\left(t_{j}, t_{j-1}\right)
$$

This final stress, in each time step, has to be compared to the concrete strength. For case of concrete in tension the limit is defined by the concrete tensile strength $\boldsymbol{f}_{c t m}$. If this tensile strength is exceeded, the contribution of this element is neglected.

For the stress evaluation in each element of a prestressed strand is necessary to compute the losses of stress due to the combination of the concrete shrinkage and creep effects as well as the steel relaxation. According to Trevino and Ghali [4] the stress loss due to the steel relaxation in a strand element $i$ is given by:

$$
\Delta \sigma_{p r i}\left(t, t_{0}\right)=\Delta \sigma_{p r o \infty}\left[\frac{1}{16} \ln \left(\frac{t-t_{0}}{240}+1\right)\right] \text { for } 0 \leq\left(t-t_{0}\right) \leq 41 \text { days }
$$

$$
\Delta \sigma_{p r i}\left(t, t_{0}\right)=\Delta \sigma_{p p r o}\left[\left(\frac{t-t_{0}}{12 \times 10^{6}}\right)^{0,2}\right] \text { for } 41 \leq\left(t-t_{0}\right) \leq 12 \times 10^{6} \text { days }
$$

$$
\Delta \sigma_{p r i}\left(t, t_{0}\right)=\Delta \sigma_{p r \infty} \text { for }\left(t-t_{0}\right)>12 \times 10^{6} \text { days }
$$

where:

$\Delta \sigma_{p r \infty}=-f_{p t k} \eta_{\infty}(\lambda-0.4)^{2}$ for $\lambda \geq 0.4$

$\Delta \sigma_{p r \infty}=0$ for $\lambda<0.4$

$\lambda=\frac{\sigma_{p i}\left(t_{0}\right)}{f_{p t k}}$

\section{$\eta_{\infty}=2.0$ for normal relaxation steel}

\section{$\eta_{\infty}=1.5$ for low relaxation steel}

Thus, the stress loss in a strand element $i$ including the concrete shrinkage and creep effects can be evaluated by:

$$
\Delta \sigma_{p i(c+s+r)}=\bar{\Delta} \sigma_{p r i}\left(t, t_{0}\right)+\left[\varepsilon_{c c i}\left(t, t_{0}\right)+\varepsilon_{c s i}\left(t, t_{0}\right)\right] E_{s}
$$

with

$\bar{\Delta} \sigma_{p r i}\left(t, t_{0}\right)=\xi_{r} \Delta \sigma_{p r i}\left(t, t_{0}\right)$

$\xi_{r}=e^{(-6.7+5.32) \Omega}$

$\Omega=\frac{\Delta \sigma_{p r i}-\Delta \sigma_{p i(c+s+r)}}{\sigma_{p i}\left(t_{0}\right)}$; if $\Omega<0$, adopt $\Omega=0$

In this case, $\Delta \sigma_{p i(c+s+r)}$ should be determined by iterative process. For the first attempt, consider $\xi_{r}=1$.

Then, the stress and strain at a strand element $\boldsymbol{i}$ at time $\boldsymbol{t}_{u+1}$ are given by:

$$
\sigma_{p i}\left(t_{u+1}, t_{p}\right)=E_{s} \varepsilon_{p i}\left(t_{u+1}, t_{p}\right)+\Delta \sigma_{p i(c+s+r)}\left(t_{u+1}, t_{p}\right)
$$

$$
\bar{\varepsilon}_{p i}\left(t_{u+1}, t_{p}\right)=\sigma_{p i}\left(t_{u+1}, t_{p}\right) / E_{s}
$$

For each strand element $i$, the maximum tensile stress is equal to the steel yield strength.

The internal axial force and bending moment in each cross section are determined as follows:

$$
N_{R}\left(t_{u+1}, t_{0}\right)=\sum_{i=1}^{c} \sigma_{c i}\left(t_{u+1}, t_{0}\right) A_{c i}+\sum_{i=1}^{p} \sigma_{p i}\left(t_{u+1}, t_{p}\right) \cos \left(\alpha_{p i}\right) A_{p i}
$$

$$
M_{R}\left(t_{u+1}, t_{0}\right)=\sum_{i=1}^{c} \sigma_{c i}\left(t_{u+1}, t_{0}\right) y_{c i} A_{c i}+\sum_{i=1}^{p} \sigma_{p i}\left(t_{u+1}, t_{p}\right) \cos \left(\alpha_{p i}\right) y_{p i} A_{p i}
$$

The equilibrium between external and internal forces in every cross-section of the hollow core slab is given by:

$$
N_{R}=N_{E X T}
$$

$$
M_{R}=M_{E X T}
$$

The correct state of strain and the corresponding equilibrium position of the slab at each time step are obtained when both equations (13) and (14) are satisfied at every cross-section. If this is 
not achieved a new strain state is introduced and the procedure is repeated.

To ensure convergence of the iterative search process for the state of strain which satisfies the equations (13) and (14), one must consider the compressive strength of concrete and steel stress unlimited. The value of these stresses should be checked at the end of the analysis. Stresses levels above usual values for service state level indicate insufficient cross-section dimensions.

After the equilibrium conditions are satisfied at each cross section, the hollow core slab deflected shape can be determined. With the strain of each concrete (equation 2) and strand (equation 10) element in every section, the curvature in each section along the slab is calculated. In this case the transverse displacement curvature relationship is given by:

$$
\frac{d^{2} y\left(t_{u+1}\right)}{d x^{2}}=-\frac{1}{r\left(t_{u+1}\right)}
$$

The rotations are obtained by integrating the above equation. Thus:

$$
\theta\left(t_{u+1}\right)=\theta_{1}\left(t_{u+1}\right)+\int_{x_{1}}^{x} \frac{1}{r\left(t_{u+1}\right)} d x
$$

Figure 1 - Details of the slabs cross-sections

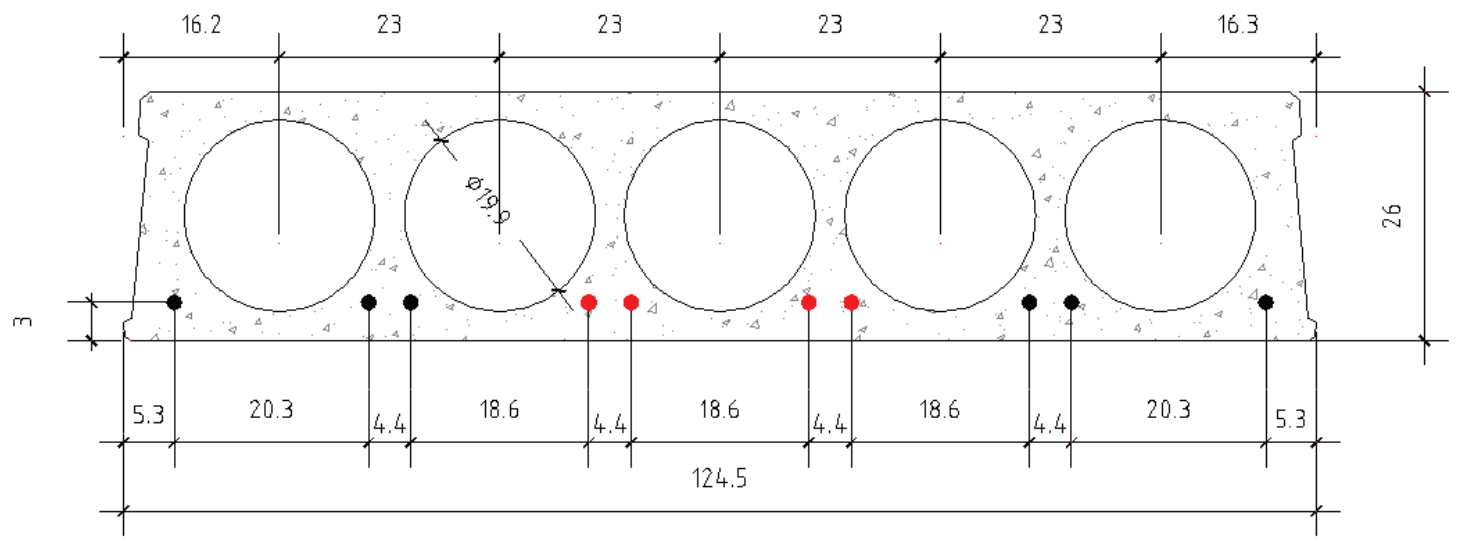

- $12.7 \mathrm{~mm}$ nominal dameter strand

- $11.1 \mathrm{~mm}$ nomfnal dtameter strand

A Series 1

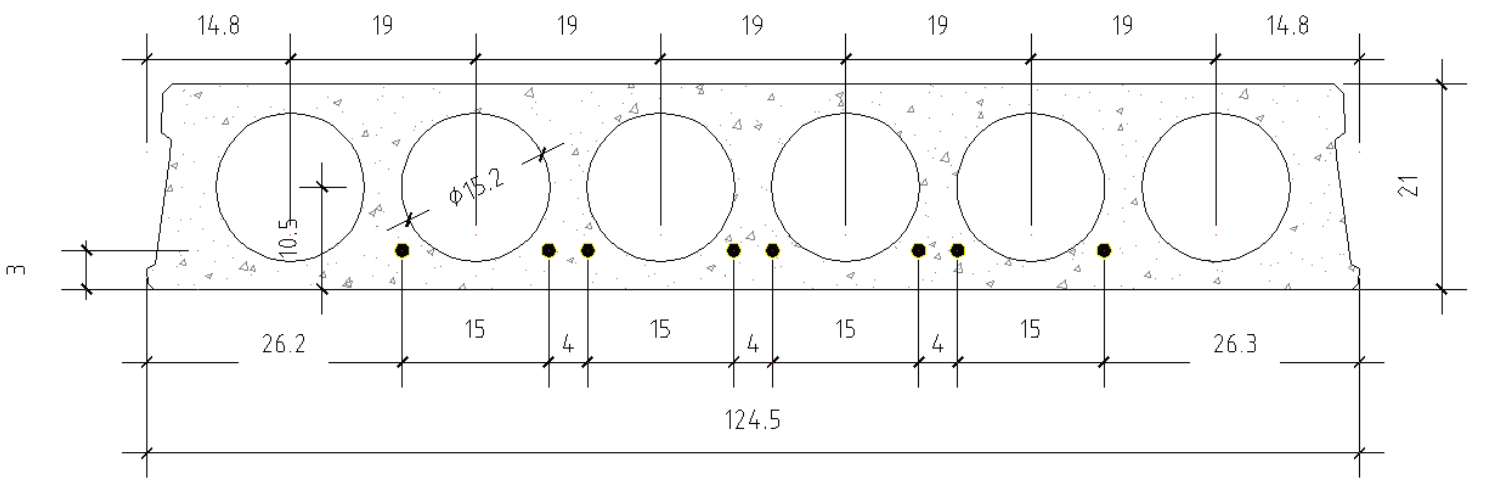

- $12.7 \mathrm{~mm}$ nomfnal dlameter strand

B Series 2 
The transverse displacements are calculated then by:

$$
y\left(t_{u+1}\right)=y_{1}\left(t_{u+1}\right)+\theta_{1}\left(t_{u+1}\right)\left(x-x_{1}\right)+\int_{x_{1}}^{x} \theta\left(t_{u}+1\right) d x
$$

Since each slab has been divided in sections and considering the number of the first section equal to 1 , the above equation is replaced by:

$$
\begin{aligned}
& y_{i}\left(t_{u+1}\right)=y_{1}\left(t_{u+1}\right)+\theta_{1}\left(t_{u+1}\right)\left(x-x_{1}\right)-\Delta \ell^{2}\left[\frac{1}{4}\left(\frac{1}{r_{l}\left(t_{u+1}\right)}+\frac{1}{r_{i}\left(t_{u+1}\right)}\right)(2 i-1)\right] \\
& -\Delta \ell^{2}\left[\frac{1}{2} \sum_{j=1}^{i-1} \frac{1}{r_{j}\left(t_{u+1}\right)}+\sum_{j=1}^{i-1} \sum_{k=1}^{j-1} \frac{1}{r_{k}\left(t_{u+1}\right)}\right]
\end{aligned}
$$

It is important to point out that equation (18) has to satisfy the slab cinematic conditions.

\section{Experimental program}

In order to verify the numerical model an experimental program was carried on. It consisted on the testing of two series of hollow core slabs. Each series had three specimens. In series 1 , the hollow core slabs were $1245 \mathrm{~mm}$ in width and $260 \mathrm{~mm}$ in depth with constant hollow cores of $199 \mathrm{~mm}$ in diameter. They were $10 \mathrm{~m}$ long and pre-tensioned with 4 seven-wire low relaxation strands ( $12.7 \mathrm{~mm}$ in nominal diameter) and 6 seven-wire low relaxation strands $(11.1 \mathrm{~mm}$ in nominal diameter). Both strands were placed with a $30 \mathrm{~mm}$ bottom cover. Slabs of series 2 had the same width and length as of series 1 but with a total depth of $210 \mathrm{~mm}$; the hollow cores were $152 \mathrm{~mm}$ in diameter. They had 8 seven-wire low relaxation strands of 12.7 $\mathrm{mm}$ in nominal diameter placed with a $30 \mathrm{~mm}$ bottom cover. Both series were pre-tensioned to $75 \%$ of the ultimate strength $f p u=1900 \mathrm{MPa}$, before the concrete was cast using dry mix extrusion procedures. The applied prestressing force was transferred to the concrete 20 hours after casting. The details of the slabs cross-sections are shown in figure 1.

The concrete was produced using Brazilian type $\mathrm{V}$ cement and limestone as coarse aggregate. Its concrete compressive strength was evaluated employing the impact hammer. The impact hammer is a practical method for determining the concrete strength of slabs cast using dry mix extrusion procedures and considerably more precise than test cylinders. This is because the compaction of the machine cannot be accurately duplicated in making the cylinders. The concrete strength was evaluated at the age of 30 days for slabs of series 1 and 35 days for series 2. These ages correspond to the initial testing time in which a uniform distributed live load was applied to each slab. The average concrete compressive strength at this age was 40.6 and $28.3 \mathrm{MPa}$ for series 1 and 2 respectively. Both of these values correspond to an average of 9 readings taken with the impact hammer in the horizontal position on the side of each slab. The correlation to compressive cylinder strengths was made with the use of curves printed on a plate attached to the instrument. This compressive strength was the only concrete mechanical property measured throughout the study.

The hollow core slab tests were conducted in an open area at Precon Industrial in Pedro Leopoldo, Minas Gerais. The test set-up is shown in figure 2 . The specimens were subjected to a uniformly distributed load on a simple span. The clear span between the supports was $9.9 \mathrm{~m}$ Cement bags, with a nominal weight of $0.5 \mathrm{kN}$ each, were used for the uniformly distributed load (figure $2 \mathrm{~b}$ ). A dial-gage placed at mid-span was used to measure the deflection.

The uniform distributed live load was applied incrementally after each slab had been placed over supports. During the first four days, loads were incrementally applied daily. Each live load increment corresponded to 1.52 and $1.01 \mathrm{kN} / \mathrm{m}$ for series 1 and 2 respectively. These loads were kept for approximately 114 days. After that period additional loads were applied up to each slab series service live load $(8.875$ and $6.65 \mathrm{kN} / \mathrm{m}$ for series 1 and 2 respectively). Before each live load increment and during the period of 127 days, mid-span deflections were measured. These readings were always taken early in the morning to avoid temperature effects.

The temperature and relative humidity were measured daily (also early in the morning) during the testing period. Their average values were calculated and correspond to $25^{\circ} \mathrm{C}$ and $40 \%$ respectively.

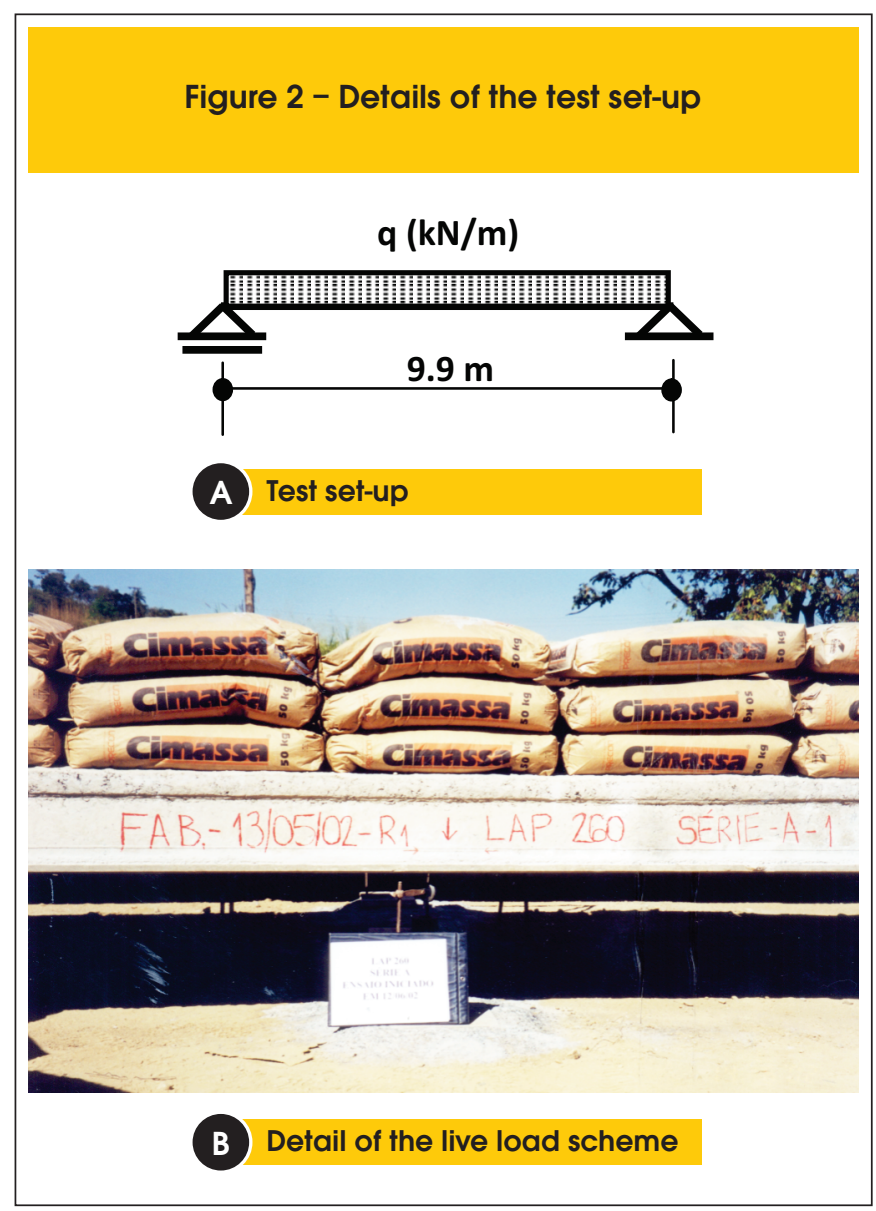




\section{Comparative study}

A comparison of the numerical and experimental results is presented herein. The mid-span deflection for each series was selected for this study since it represents the overall behavior the hollow core slabs. It is important to point out that the comparison is carried out during a 4-month loading period in which the values of the loads were at or below service level.

In the numerical model, the concrete properties including shrinkage and creep effects were derived from the compressive strength measured at the initial testing time and from the temperature and relative humidity average values shown before. For a proper evaluation of the needed parameters, the formulation prescribed in NBR 6118 sections 8.2.8, 12.3.3, A.2.2.3 and A.2.3.2 was used. For each slab,
10 cross-sections along the span were analyzed at each time step with 50 concrete elements in every cross-section. The number of strand elements in every cross-section corresponded to the number of strands for each slab series: 10 for series 1 and 8 for series 2 .

The results of the comparative study are presented both in tabular and graphical form. Table 1 shows the results for slabs of Series 1 while the values correspondent to slabs of Series 2 are in table 2. The comparison between the actual and predicted overall behavior can be quantified based on the model error $y$ defined as the ratio between the evaluated mid-span deflection and the measured value. Values of y (last columns of tables 1 and 2) smaller than the unity indicate a stiffer behavior predicted by the numerical model. Each graph, on the other hand, shows an overall visual comparison. The comparative study for slabs of Series 1 is well represented in figure 3 which shows the load versus the midspan deflection

Table 1 - Results for slabs of Series 1

\begin{tabular}{|c|c|c|c|c|c|}
\hline Specimen & $\begin{array}{l}\text { Uniform distributed } \\
\text { live load } \\
\text { (kN/m) }\end{array}$ & $\begin{array}{l}\text { Age } \\
\text { (days) }\end{array}$ & $\begin{array}{l}\text { Measured mid-span } \\
\text { deflection } \\
(\mathrm{cm})\end{array}$ & $\begin{array}{l}\text { Evaluated mid-span } \\
\text { deflection } \\
(\mathrm{cm})\end{array}$ & Model error $\psi^{*}$ \\
\hline \multirow{17}{*}{ Slab A1 } & 0.00 & 0 & 0.000 & 0.000 & - \\
\hline & 1.52 & 0.02 & 0.300 & 0.340 & 1.13 \\
\hline & 3.03 & 1 & 0.650 & 0.820 & 1.26 \\
\hline & 4.55 & 2 & 0.985 & 1.310 & 1.33 \\
\hline & 6.06 & 3 & 1.350 & 1.820 & 1.35 \\
\hline & 6.06 & 7 & 1.800 & 2.180 & 1.21 \\
\hline & 6.06 & 10 & 2.000 & 2.260 & 1.13 \\
\hline & 6.06 & 14 & 2.100 & 2.340 & 1.11 \\
\hline & 6.06 & 19 & 2.250 & 2.40 & 1.07 \\
\hline & 6.06 & 22 & 2.225 & 2.430 & 1.09 \\
\hline & 6.06 & 43 & 2.050 & 2.540 & 1.24 \\
\hline & 6.06 & 60 & 2.100 & 2.590 & 1.23 \\
\hline & 6.06 & 66 & 2.275 & 2.600 & 1.14 \\
\hline & 6.06 & 78 & 2.375 & 2.620 & 1.10 \\
\hline & 6.06 & 114 & 2.100 & 2.650 & 1.26 \\
\hline & 7.58 & 119 & 2.450 & 2.980 & 1.22 \\
\hline & 9.09 & 119.02 & 2.750 & 3.330 & 1.21 \\
\hline \multirow{13}{*}{ Slab A2 } & 0.00 & 0 & 0.000 & 0.000 & - \\
\hline & 1.52 & 0.02 & 0.600 & 0.340 & 0.57 \\
\hline & 3.03 & 1 & 0.875 & 0.820 & 0.94 \\
\hline & 4.55 & 2 & 1.200 & 1.310 & 1.09 \\
\hline & 6.06 & 3 & 1.675 & 1.820 & 1.09 \\
\hline & 6.06 & 7 & 2.100 & 2.180 & 1.04 \\
\hline & 6.06 & 10 & 2.225 & 2.260 & 1.02 \\
\hline & 6.06 & 14 & 2.300 & 2.340 & 1.02 \\
\hline & 6.06 & 16 & 2.325 & 2.370 & 1.02 \\
\hline & 6.06 & 20 & 2.425 & 2.410 & 0.99 \\
\hline & 6.06 & 66 & 2.475 & 2.600 & 1.05 \\
\hline & 6.06 & 78 & 2.550 & 2.620 & 1.03 \\
\hline & 8.89 & 121.06 & 2.750 & 3.250 & 1.18 \\
\hline
\end{tabular}




\section{Table 2 - Results for slabs of Series 1 (continuation)}

\begin{tabular}{|c|c|c|c|c|c|}
\hline Specimen & $\begin{array}{l}\text { Uniform distributed } \\
\text { live load } \\
(\mathrm{kN} / \mathrm{m})\end{array}$ & $\begin{array}{l}\text { Age } \\
\text { (days) }\end{array}$ & $\begin{array}{l}\text { Measured mid-span } \\
\text { deflection } \\
(\mathrm{cm})\end{array}$ & $\begin{array}{l}\text { Evaluated mid-span } \\
\text { deflection } \\
(\mathrm{cm})\end{array}$ & Model error $\psi^{*}$ \\
\hline \multirow{14}{*}{ Slab A3 } & 0,00 & 0 & 0.000 & 0.000 & - \\
\hline & 1.52 & 0.02 & 0.375 & 0.340 & 0.91 \\
\hline & 3.03 & 1 & 0.625 & 0.820 & 1.31 \\
\hline & 4.55 & 2 & 0.960 & 1.310 & 1.36 \\
\hline & 6.06 & 3 & 1.400 & 1.820 & 1.30 \\
\hline & 6.06 & 8 & 1.850 & 2.210 & 1.19 \\
\hline & 6.06 & 12 & 1.925 & 2.310 & 1.20 \\
\hline & 6.06 & 15 & 2.000 & 2.350 & 1.18 \\
\hline & 6.06 & 22 & 2.050 & 2.430 & 1.19 \\
\hline & 6.06 & 43 & 2.050 & 2.540 & 1.24 \\
\hline & 6.06 & 60 & 2.100 & 2.590 & 1.23 \\
\hline & 6.06 & 66 & 2.100 & 2.600 & 1.24 \\
\hline & 6.06 & 78 & 2.200 & 2.620 & 1.19 \\
\hline & 8.89 & 125.06 & 2.900 & 3.250 & 1.12 \\
\hline
\end{tabular}

along 119 days for specimen A1. These results reveal a less stiff behavior predicted by the numerical model throughout the load spectrum investigated. The overall comparison for the slabs of this Series is made based on the statistical analyses of $y$ which include its average $(\mathrm{m})$, the standard deviation (s) as well as its coefficient of variation (COV). The average of $y$ is used as a measure of the conservativeness of the numerical modeling and the coefficient of variation is taken as an indication of its accuracy. These values are presented in table 3 . The analysis of these results shows that the model predicts conservatively and accurately the measured midspan deflections with a model error average of 1.14 and COV of $12.6 \%$ for all the slabs of this series.

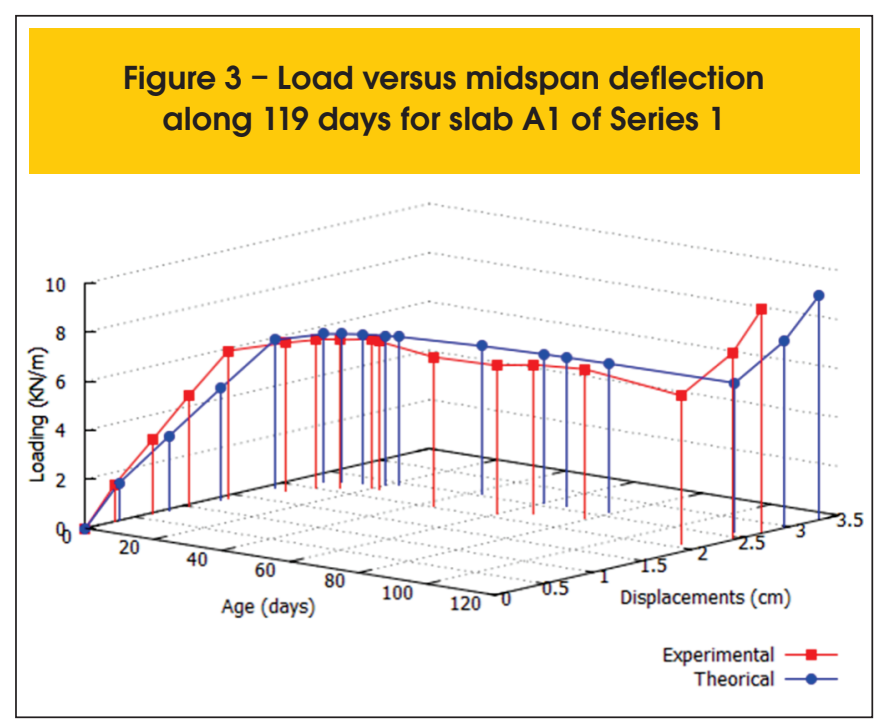

The load versus the midspan deflection along 126 days for Series 2 (slab B2) is presented in Figure 4. It can be seen that the numerical model predicts well the observed behavior. The statistical analysis (table 3 ) for this series also shows that the numerical procedure evaluates conservatively the measured midspan deflections. On the other hand the model was less accurate in this case since the COV was equal to $25 \%$ for all the slabs of this series.

The overall analysis of the comparative study indicates the conservative bias of the numerical procedure: model error average equals to 1.10 for all the slabs investigated. With respect to accuracy, the modeling also shows good results with an overall COV of $20 \%$.

\section{Figure 4 - Load versus midspan deflection along 126 days for slab B2 of Series 2}

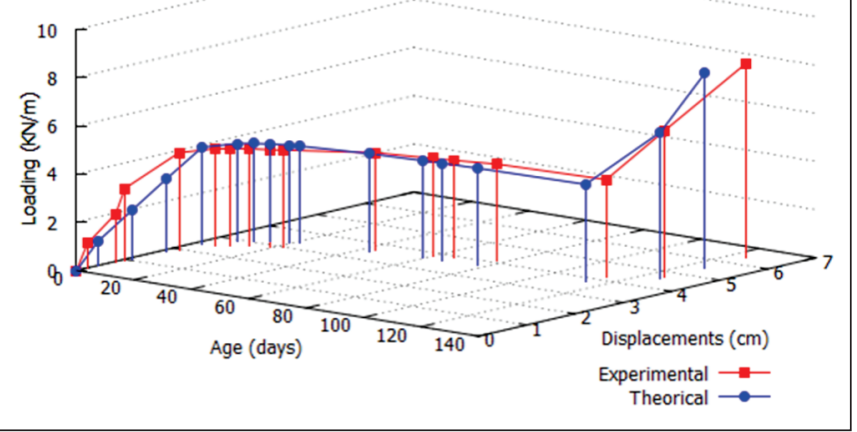


The midspan deflection, temperature and relative humidity measurements were taken daily at the same hour (early in the morning) during the investigation campaign. This is an important aspect of the research and it may be one of the reasons for the good correlation achieved between the experimental and modeling results.

\section{Conclusions}

A numerical model for the analysis of prestressed hollow core slabs under long term loading has been presented. The model considers explicitly the geometrical changes in cross section as well as the time dependence of the loads and of material properties in order to predict the actual stage of displacements, strains and stresses. The numerical results were compared with experimental tests performed on two series of prestressed hollow core slabs. Each series had a different geometry, rate and distribution of prestressing strands as well as material properties. Loads and mid-span displacements were evaluated up to 127 days after initial loading. The overall analysis of the comparative study indicates the conservative bias of the numerical procedure: model error average equals to 1.10 for all the slabs investigated. With respect to accuracy, the modeling scheme also shows good results with an overall COV of $20 \%$.

Table 2 - Results for slabs of Series 2

\begin{tabular}{|c|c|c|c|c|c|}
\hline Specimen & $\begin{array}{l}\text { Uniform distributed } \\
\text { live load } \\
\text { (kN/m) }\end{array}$ & $\begin{array}{l}\text { Age } \\
\text { (days) }\end{array}$ & $\begin{array}{l}\text { Measured mid-span } \\
\text { deflection } \\
(\mathrm{cm})\end{array}$ & $\begin{array}{l}\text { Evaluated mid-span } \\
\text { deflection } \\
(\mathrm{cm})\end{array}$ & Model error $\psi^{*}$ \\
\hline \multirow{16}{*}{ Slab B1 } & 0.00 & 0.00 & 0.000 & 0.000 & - \\
\hline & 1.01 & 0.02 & 0.400 & 0.500 & 1.25 \\
\hline & 2.02 & 1 & 0.925 & 1.260 & 1.36 \\
\hline & 3.03 & 2 & 1.550 & 2.020 & 1.30 \\
\hline & 4.04 & 3 & 2.350 & 2.810 & 1.20 \\
\hline & 4.04 & 7 & 2.875 & 3.460 & 1.20 \\
\hline & 4.04 & 10 & 3.100 & 3.630 & 1.17 \\
\hline & 4.04 & 14 & 3.225 & 3.790 & 1.18 \\
\hline & 4.04 & 19 & 3.300 & 3.930 & 1.19 \\
\hline & 4.04 & 22 & 3.325 & 3.990 & 1.20 \\
\hline & 4.04 & 43 & 4.125 & 4.270 & 1.04 \\
\hline & 4.04 & 60 & 4.200 & 4.410 & 1.05 \\
\hline & 4.04 & 114 & 4.550 & 4.650 & 1.02 \\
\hline & 5.05 & 125.08 & 4.950 & 5.100 & 1.03 \\
\hline & 6.06 & 125.1 & 5.700 & 5.620 & 0.99 \\
\hline & 7.07 & 125.12 & 6.400 & 6.150 & 0.96 \\
\hline \multirow{17}{*}{ Slab B2 } & 0.00 & 0.00 & 0.000 & 0.000 & - \\
\hline & 1.01 & 0.02 & 0.225 & 0.450 & 2.00 \\
\hline & 2.02 & 1 & 0.755 & 1.100 & 1.46 \\
\hline & 3.03 & 2 & 0.885 & 1.750 & 1.98 \\
\hline & 4.04 & 3 & 1.950 & 2.430 & 1.25 \\
\hline & 4.04 & 7 & 2.475 & 2.930 & 1.18 \\
\hline & 4.04 & 10 & 2.600 & 3.070 & 1.18 \\
\hline & 4.04 & 14 & 2.750 & 3.180 & 1.16 \\
\hline & 4.04 & 19 & 2.875 & 3.290 & 1.14 \\
\hline & 4.04 & 22 & 2.975 & 3.330 & 1.12 \\
\hline & 4.04 & 43 & 3.625 & 3.530 & 0.97 \\
\hline & 4.04 & 60 & 3.825 & 3.620 & 0.95 \\
\hline & 4.04 & 66 & 3.900 & 3.650 & 0.94 \\
\hline & 4.04 & 78 & 4.075 & 3.690 & 0.91 \\
\hline & 4.04 & 114 & 4.200 & 3.770 & 0.90 \\
\hline & 6.06 & 126.04 & 4.675 & 4.610 & 0.99 \\
\hline & 8.08 & 126.06 & 6.375 & 5.530 & 0.87 \\
\hline
\end{tabular}




\section{Acknowledgements}

The authors would like to thank Universidade Federal de Minas Gerais (UFMG) and PRECON Industrial for the financial and infrastructural support.

\section{References}

[01] PRECAST/PRESTRESSED CONCRETE INSTITUTE, $\mathrm{PCl}$ Manual for the Design of Hollow Core Slabs 2nd edition; Chicago, Illinois, 1998.

Table 2 - Results for slabs of Series 2 - (continuation)

\begin{tabular}{|c|c|c|c|c|c|}
\hline Specimen & $\begin{array}{l}\text { Uniform distributed } \\
\text { live load } \\
(\mathrm{kN} / \mathrm{m})\end{array}$ & $\begin{array}{c}\text { Age } \\
\text { (days) }\end{array}$ & $\begin{array}{l}\text { Measured mid-span } \\
\text { deflection } \\
(\mathrm{cm})\end{array}$ & $\begin{array}{l}\text { Evaluated mid-span } \\
\text { deflection } \\
(\mathrm{cm})\end{array}$ & Model error $\psi^{*}$ \\
\hline \multirow{17}{*}{ Slab B3 } & 0.00 & 0.00 & 0.000 & 0.000 & - \\
\hline & 1.01 & 0.02 & 0.400 & 0.500 & 1.25 \\
\hline & 2.02 & 1 & 1.005 & 1.270 & 1.26 \\
\hline & 3.03 & 2 & 2.000 & 2.040 & 1.02 \\
\hline & 4.04 & 3 & 2.875 & 2.840 & 0.99 \\
\hline & 4.04 & 7 & 3.775 & 3.500 & 0.93 \\
\hline & 4.04 & 10 & 4.000 & 3.680 & 0.92 \\
\hline & 4.04 & 14 & 4.175 & 3.840 & 0.92 \\
\hline & 4.04 & 19 & 4.250 & 3.990 & 0.94 \\
\hline & 4.04 & 22 & 4.400 & 4.050 & 0.92 \\
\hline & 4.04 & 43 & 5.550 & 4.340 & 0.78 \\
\hline & 4.04 & 60 & 6.000 & 4.480 & 0.75 \\
\hline & 4.04 & 66 & 6.125 & 4.530 & 0.74 \\
\hline & 4.04 & 78 & 6.200 & 4.590 & 0.74 \\
\hline & 4.04 & 114 & 6.850 & 4.740 & 0.69 \\
\hline & 6.06 & 127.04 & 7.900 & 5.680 & 0.72 \\
\hline & 8.08 & 127.06 & 9.650 & 6.870 & 0.71 \\
\hline
\end{tabular}

\begin{tabular}{|c|c|c|c|c|}
\hline \multicolumn{5}{|c|}{ Table 3 - Statistical analysis of the model error $\psi$} \\
\hline \multirow{2}{*}{$\begin{array}{l}\text { Statistical parameters } \\
\text { of the model error } \psi\end{array}$} & \multicolumn{4}{|c|}{ Series 1} \\
\hline & Slab Al & Slab A2 & Slab A3 & All slabs \\
\hline Average $\mu$ & 1.19 & 1.00 & 1.20 & 1.14 \\
\hline Standard deviation $\sigma$ & 0.0847 & 0.1493 & 0.1106 & 0.1439 \\
\hline \multirow[t]{3}{*}{$\operatorname{cov}(\%)$} & 7.10 & 14.93 & 9.18 & 12.61 \\
\hline & \multicolumn{4}{|c|}{ Series 2} \\
\hline & Slab B1 & Slab B2 & Slab B3 & All slabs \\
\hline Average $\mu$ & 1.14 & 1.19 & 0.89 & 1.07 \\
\hline Standard deviation $\sigma$ & 0.1208 & 0.3504 & 0.1788 & 0.2688 \\
\hline \multirow[t]{2}{*}{$\operatorname{cov}(\%)$} & 10.58 & 29.54 & 20.03 & 25.07 \\
\hline & \multicolumn{4}{|c|}{ Series $1+$ Series 2} \\
\hline Average $\mu$ & \multicolumn{4}{|c|}{1.10} \\
\hline Standard deviation $\sigma$ & \multicolumn{4}{|c|}{0.2212} \\
\hline $\operatorname{cov}(\%)$ & \multicolumn{4}{|c|}{20.03} \\
\hline
\end{tabular}


[02] PEREIRA, S. S. R. Análise do Comportamento Reológico de Pontes em Balanços Sucessivos, Doctoral Thesis, COPPE - Universidade Federal do Rio de Janeiro, February, 1999.

[3] ASSOCIAÇÃO BRASILEIRA DE NORMAS TÉCNICAS, NBR 6118 - Projeto de Estruturas de Concreto Procedimento, Rio de Janeiro, 2007.

[4] TREVINO, J. and GHALI, A. Relaxation of Steel in Prestressed Concrete, Prestressed Concrete Institute Journal, vol. 30, n. 5, September-October, 1985, p. 82-94.

\section{Notation}

The following symbols are used in this paper:

$\varepsilon_{c i}\left(t_{u}, t_{o}\right)=$ total strain in a concrete element $\boldsymbol{i}$ in time $\boldsymbol{t}_{\boldsymbol{u}}$;

$\varepsilon_{c i}\left(t_{u+1}, t_{o}\right)=$ total strain in a concrete element $\boldsymbol{i}$ in time $\boldsymbol{t}_{\boldsymbol{u}+\boldsymbol{1}}$;

$\varepsilon_{c c i}\left(t, t_{o}\right)=$ creep strain in a concrete element $\boldsymbol{i}$ in time $\boldsymbol{t}$;

$\mathcal{E}_{c s i}\left(t, t_{o}\right)=$ shrinkage strain in a concrete element $\boldsymbol{i}$ in time $\boldsymbol{t}$;

$\varepsilon_{p i}\left(t_{u+1}, t_{p}\right)=$ strain in a strand element $\boldsymbol{i}$ after initial losses;

$\bar{\varepsilon}_{p i}\left(t_{u+1}, t_{o}\right)=$ total strain in a strand element $\boldsymbol{i}$ in time $\boldsymbol{t}_{\boldsymbol{u}+\boldsymbol{1}}$;

$E_{c}(\tau)=$ concrete tangent modulus of elasticity at time $\tau$

(NBR 6118 sections 12.3 .3 and 8.2.8);

$E_{c 28}=$ concrete tangent modulus of elasticity at time 28 days (NBR 6118 section 8.2.8);

$E_{s}=$ steel modulus of elasticity;

$f_{c t m}=$ average concrete tensile strength;

$\varphi\left(t_{u}, \tau\right)=$ creep coefficient (NBR 6118 section A.2.2.3);

$\varepsilon_{c s \infty}=$ maximum shrinkage strain (NBR 6118 section A.2.3.2);

$t_{0}=$ initial time in which the stress state changes in a cross section;

$t_{p}=$ time of the prestressing force transfer to the concrete slab;

$t_{s}=$ time corresponding to the end of the curing period;

$\beta_{s}\left(t_{u}\right)=$ function that describes the development of shrinkage strain along the time; (NBR 6118 section A.2.3.2);

$\Delta \sigma_{c i}\left(t_{j}, t_{j-1}\right)=$ incremental stress in a concrete element $i$ between times $\boldsymbol{t}_{\boldsymbol{j}}$ and $\boldsymbol{t}_{\boldsymbol{j}-\boldsymbol{1}}$

$\Delta \sigma_{p r i}\left(t, t_{0}\right)=$ stress loss in a strand element $i$ due to steel relaxation between times $\boldsymbol{t}$ and $\boldsymbol{t}_{\boldsymbol{0}}$;

$\lambda=$ stress intensity ratio in a prestressed strand;

$\eta_{\infty}=$ steel relaxation coefficient;
$\Delta \sigma_{\text {pro }}=$ maximum stress loss in a strand due to steel relaxation;

$\Omega=$ error coefficient of iteration process;

$\xi_{r}=$ steel relaxation correction coefficient;

$\Delta \sigma_{p i(c+s+r)}=$ stress loss in a strand element $i$ due to the combination of concrete shrinkage and creep effects as well as steel relaxation;

$A_{c i}=$ area of the concrete element $i$;

$A_{p i}=$ area of the strand element $i$;

$y_{c i}=$ distance from the center of gravity of concrete element $i$ to the top fiber of the slab cross-section;

$y_{p i}=$ distance from steel element $\boldsymbol{i}$ to the top fiber of the slab cross-section;

$\alpha_{p i}=$ inclination angle of strand element $i$ in a slab cross-section; $M_{R}\left(t_{u+1}, t_{0}\right)=$ internal bending moment at time $\boldsymbol{t}_{\boldsymbol{u}+\boldsymbol{1}}$;

$N_{R}\left(t_{u+1}, t_{0}\right)=$ internal axial force at time $\boldsymbol{t}_{\boldsymbol{u}+\boldsymbol{1}}$;

$N_{E X T}=$ external axial force in a slab cross-section;

$M_{E X T}=$ external bending moment in a slab cross-section;

$r\left(t_{u+1}\right)=$ radius of curvature of a generic cross-section at time $t_{u+1}$

$r_{j}\left(t_{u+1}\right)=$ radius of curvature of cross-section $\boldsymbol{j}$ at time $\boldsymbol{t}_{\boldsymbol{u}+\boldsymbol{1}}$;

$\theta\left(t_{u+1}\right)=$ rotation of a generic cross-section at time $t_{u+1}$;

$\theta_{j}\left(t_{u+1}\right)=$ rotation of cross-section $j$, at a distance $j_{1}$ from the origin, at time $t_{u+1}$;

$y\left(t_{u+1}\right)=$ transverse displacement of a generic cross-section at time $t_{u+1}$;

$y_{j}\left(t_{u+1}\right)=$ transverse displacement of cross-section $j$, at a distance $j_{1}$ from the origin, at time $t_{u+1}$;

$\Delta \ell_{(i, i+1)}=$ longitudinal distance between cross sections $\boldsymbol{i}$ and $\boldsymbol{i + 1}$. 